Article

\title{
Exploring the Knowledge and Perceptions of Local Communities on Illegal Hunting: Long-Term Trends in a West African Protected Area
}

\author{
Jerry Owusu Afriyie ${ }^{1}$, Michael Opare Asare ${ }^{2}$ and Pavla Hejcmanová ${ }^{1,3, *(D)}$ \\ 1 Faculty of Tropical AgriSciences, Czech University of Life Sciences Prague, Kamýcká 129, \\ 16500 Prague, Czech Republic; owusu_afriyie@ftz.czu.cz \\ 2 Faculty of Environmental Sciences, Czech University of Life Sciences Prague, Kamýcká 129, \\ 16500 Prague, Czech Republic; asare@fzp.czu.cz \\ 3 Institute of Zoology, Zoological Society of London, London NW1 4RY, UK \\ * Correspondence: hejcmanova@ftz.czu.cz
}

Citation: Afriyie, J.O.; Asare, M.O.; Hejcmanová, P. Exploring the Knowledge and Perceptions of Local Communities on Illegal Hunting: Long-Term Trends in a West African Protected Area. Forests 2021, 12, 1454. https://doi.org/10.3390/f12111454

Academic Editors: Timothy A. Martin and Panayiotis Dimitrakopoulos

Received: 19 September 2021

Accepted: 22 October 2021

Published: 25 October 2021

Publisher's Note: MDPI stays neutral with regard to jurisdictional claims in published maps and institutional affiliations.

Copyright: (c) 2021 by the authors. Licensee MDPI, Basel, Switzerland. This article is an open access article distributed under the terms and conditions of the Creative Commons Attribution (CC BY) license (https:// creativecommons.org/licenses/by/ $4.0 /)$.

\begin{abstract}
Local communities in rural areas are dependent on hunting for their livelihoods and rely on their knowledge to understand wildlife ecology. Their knowledge and perceptions may be vital for forming effective and sustainable management plans related to wildlife conservation. We aimed to examine perceptions of local people living inside ( $n=153$ households) and outside ( $n=178$ households) the Kogyae Strict Nature Reserve (KSNR, Ghana) regarding bushmeat prevalence and long-term trends in illegal hunting, and to explore people's knowledge about hunting tools, species, and reasons to hunt illegally. Perceptions of bushmeat sightings and illegal hunting trends were influenced by living inside or outside the protected area, gender, and residence time. Residents living inside the reserve perceived bushmeat and hunting as frequently present in their environment mainly due to frequent sightings of bushmeat and other wildlife products, while people living adjacent to the KSNR were more knowledgeable about the decrease in illegal hunting trends, probably because of awareness about penalties and biodiversity conservation. Furthermore, the perceptions of most residents about the decrease in hunting over time were validated by long-term KSNR law enforcement data. The perception in local communities that snares were the commonest form of hunting equipment used was also consistent with the ranger-based monitoring data. The need for money, bushmeat, unemployment, and retaliatory killings were the main drivers for illegal hunting. Our findings indicated that local people's knowledge can have a valid relevance in protected area management and may assist in developing effective conservation strategies and in overall improvement of local socio-ecological systems.
\end{abstract}

Keywords: bushmeat; conservation strategies; human-wildlife conflict; illegal hunting; law enforcement; protected area management; socio-economic survey; wildlife conservation

\section{Introduction}

In most African countries, hunting and trading of bushmeat is a significant component of rural and even national economies [1]. Bushmeat contributes significantly to food security and is often a vital source of protein for rural people $[2,3]$ while causing a severe threat to wildlife populations [4,5].

The increase in the human population and easy access to markets has escalated the demand for bushmeat. These factors are also associated with the increased use of guns instead of traditional methods such as bows, arrows, and pitfalls [6,7]. Strict protection and law enforcement patrols within and around protected areas are fundamental for successful biodiversity conservation and protected area management [8]. Intensifying the patrol efforts in protected areas ensures a decrease in illegal hunting activities [9]. Meanwhile, the economic benefits from the sale of bushmeat and other wildlife products remain higher 
than the costs associated with the probability of arrest and punitive fines [10]. Furthermore, hunting activities intensify with increased human population density inside or adjacent to protected areas $[11,12]$ and decline with increasing distance of human settlements from protected area boundaries [13]. The trends in hunting activities are also associated with the benefits local communities gain from wildlife conservation projects, i.e., if local communities are involved in protected area management and economically or otherwise gain from this, it creates a win-win situation whereby wildlife is conserved and at the same time community welfare is improved [14].

Fundamental drivers for illegal hunting by people living in rural areas in proximity to protected areas are associated with limited opportunities for formal employment, leading to high levels of unemployment and poverty $[10,15]$. Besides basic livelihood needs, hunting is driven by people's values and a sense of ownership regarding the use of wildlife resources [16], and therefore individual attitudes, behaviour, and decision-making are critical motivators [17]. However, values, experience, and knowledge influence individual attitudes [18,19]. The knowledge of local people about their environment is acquired through their interactions and relationship with it, i.e., the resource management practices that local people use and their related social institutions and worldviews, which may have been passed down over generations [20].

Local people's socio-economic and cultural backgrounds are diverse, and people's livelihoods rely on their knowledge of local wildlife ecology [21]. Social aspects of conservation studies therefore tend to be site- and ecosystem-specific, despite the existence of some cross-culturally consistent patterns, such as level of education and gender [22,23]. Socio-ecological research on illegal hunting activities has mainly focused on moist forest ecosystems in Africa [24,25], while specific studies on the knowledge and perceptions of local communities regarding illegal hunting activities in other West African ecosystems are still rare.

Understanding why people poach and trade bushmeat, and their socio-economic contexts and resulting perceptions, is essential for developing strategies for designing appropriate ways to manage wildlife and reduce illegal hunting activities [16,26]. In addition, conservation strategies for PAs which are understood, legitimized, and accepted by local people contribute to building positive relationships between the parks and local people and are beneficial to overall conservation success [27].

In this study, we aimed to expand the understanding of local communities' knowledge and perceptions of illegal hunting in the Kogyae Strict Nature Reserve (KSNR) in Ghana. The KSNR is composed of a unique ecological unit with undisturbed habitats (the strictly protected zone, at $57 \%$ of the total area) and other zones, including a special-use zone where some farming and other human settlement activities are allowed $(20 \%)$. This protected-area setting offers an opportunity to explore variations between the perceptions of local people connected directly with the protected area by living inside it and those of local people living in the adjacent area, i.e., outside the protected area. Our objectives were therefore: (1) to examine the knowledge and perceptions of residents living inside and adjacent to the KSNR on the prevalence of bushmeat and long-term trends in illegal hunting activities, together with reasons for their perceptions; (2) to examine whether these perceptions vary according to people's socio-demographic characteristics, such as age group, gender, place of residence, length of residence, level of education, and occupation; (3) to explore the hunting equipment used, the species hunted, and the reasons for local people to hunt in the KSNR. To provide comparability, we complemented the knowledge and perceptions of local people about illegal hunting trends with long-term ranger-based monitoring data (Appendix B).

\section{Materials and Methods}

\subsection{Study Area}

The KSNR (map reference $7^{\circ} 08^{\prime} \mathrm{N}$ to $7^{\circ} 21^{\prime} \mathrm{N}, 0^{\circ} 59^{\prime} \mathrm{W}$ to $1^{\circ} 14^{\prime} \mathrm{W}$; Figure 1 ) is in the Afram Plains region of Ghana and covers an area of $386 \mathrm{~km}^{2}$. The park is flat with an 
average altitude of $120 \mathrm{~m}$ a.s.l. The area serves as a watershed for a network of streams dominated by tributaries of the Afram and Sene rivers, most of which dry up in the dry season. The climate has dry (from November to March) and wet (from May to October) seasons, with annual rainfall ranging between 1200 and $1300 \mathrm{~mm}$. The KSNR lies in the transitional zone between the transitional woodland (semi-deciduous forest) and the Guinea savannah woodland and open grasslands of Ghana. The reserve supports primates, ungulates, and bird species. As KSNR is unfenced, animals move in and out of the park to the adjacent communal areas.

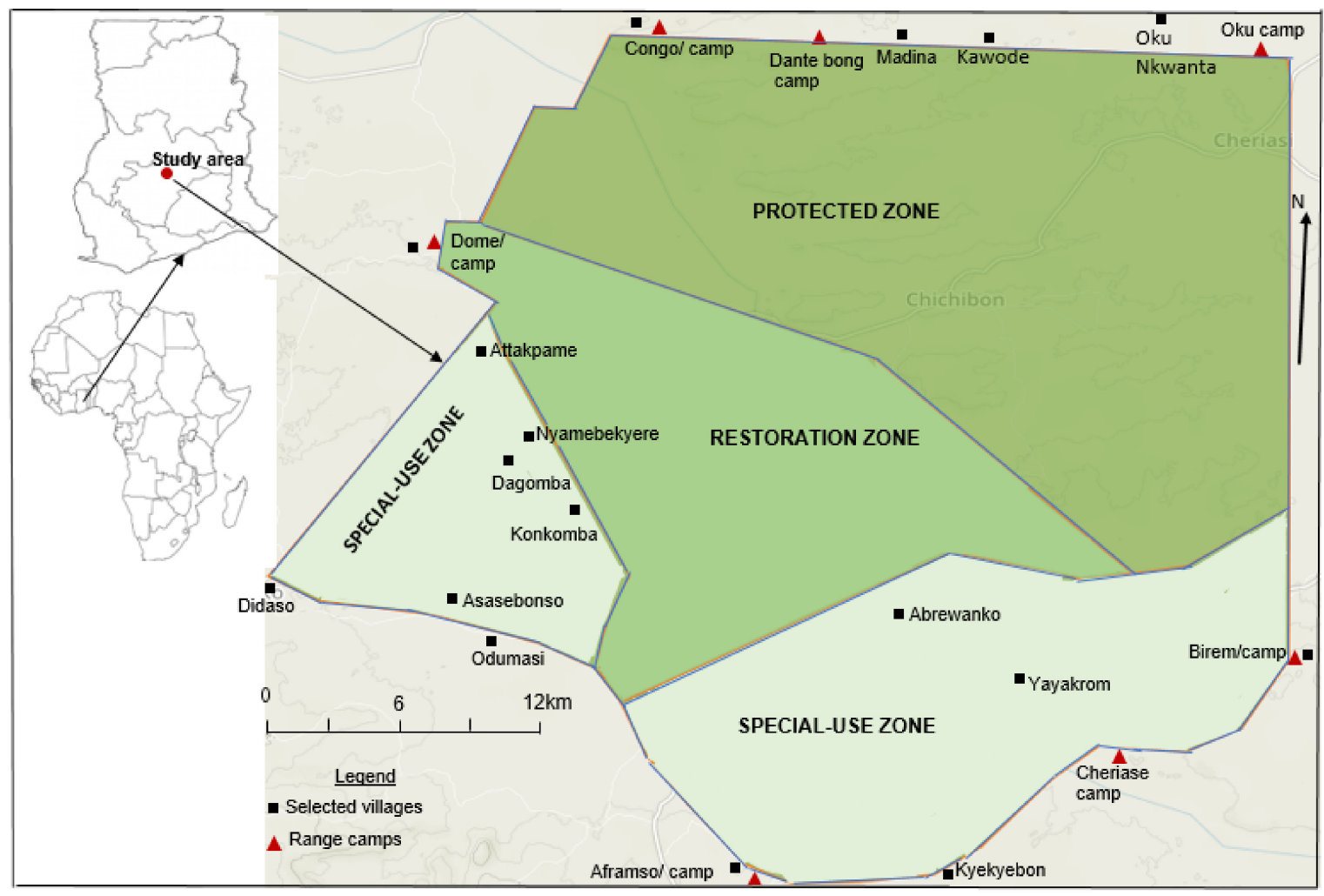

Figure 1. Map of Kogyae Strict Nature Reserve showing the locations of study communities and rangers' camps.

The KSNR is the extended version of the former Kujani Forest Reserve, managed under the Forestry Department of Ghana at that time. In 1971, the Wildlife Division took over the administration of the reserve for strict protection under the Wildlife Reserve Regulations LI 710. The extension of the Kujani Forest Reserve boundaries was to obtain a viable ecological unit for the KSNR [28]. Studies conducted by the Wildlife Division indicated that in the dry season, animals from the park depended on the rivers in the unprotected areas for survival [29]. The extension also included some communities, namely, Asasebonso, Atakpame, Nyamekyere Dagomba, Birem, Yahayakura, Aberewanko, and Konkomba. Additionally, Aframso, Birem, Kyekyebon, and Kyeiase are now on the immediate border of the reserve. The local communities are predominantly farmers, with up to $75 \%$ of the people working in the agriculture sector. Farming practices involve a slash-and-burn method of land preparation and the cultivation of a variety of crops, e.g., yams, maize, paddy rice, groundnuts, cassava, cowpeas, and vegetables. Around $15 \%$ and $10 \%$ of the population work in the industry and service sectors, respectively, with a growth rate of $1.4 \%$ per year [30]. In Ghana, the Wildlife Conservation Regulations 1971 (LI 685) allow the provision of hunting licenses for the hunting of certain species at specified times in the year. However, because of KSNR's status as a strict nature reserve, no hunting is allowed there.

KSNR has four management zones: The Protected, Special-use, Restoration, and Development Zones. The Protected Zone is the largest in the KSNR; it covers $220 \mathrm{~km}^{2}$ and 
represents $57 \%$ of the protected area. However, this area represents the most important and least disturbed habitat and is fully dedicated to conservation. Human activities such as farming, logging, and charcoal production have severely degraded the Restoration Zone. It covers $86 \mathrm{~km}^{2}$, representing 22\% of the KSNR. The Special-use Zone is an area where some farming activities are allowed for local inhabitants but no hunting or timber logging. It has a size of $79 \mathrm{~km}^{2}$ and represents $20 \%$ of the KSNR. The Development Zone has been set aside for staff accommodation, administration facilities (headquarters), the mini research station, and a centre for conservation education. This constitutes $1 \mathrm{~km}^{2}(1 \%)$ of the reserve area.

\subsection{Data Collection}

We conducted a household survey from August to September 2018 in local communities residing in and around the KSNR to collect data on their knowledge and perceptions regarding wildlife hunting and the KSNR protected area. The research was approved by the Wildlife Division of Ghana, the authority for the KSNR, and by the local communities' chiefs.

We selected all communities inside the KSNR (Asasebonso, Atakpame, Nyamekyere Dagomba, Yahayakura, Aberewanko, and Konkomba). Additionally, we randomly selected 12 communities out of the 18 located $\leq 5 \mathrm{~km}$ outside the KSNR (Berem, Odumasi, Didaso, Aframso, Cheriase, Dome, Madina, Oku Nkwanta, Congo Nkwanta, Madina, Kyekyebon, and Kawode; see Figure 1). For good coverage, we visually divided each community into four and randomly selected a household head or an adult family member $\geq 18$ years old based on those who were present in each household, until the required sample size was reached. Therefore, each household had an equal chance of been selected for the study. We randomly selected respondents who were $\geq 18$ years old because local knowledge may be acquired through long-term observations, experiences, and interactions between humans and local ecosystems. Moreover, this knowledge may be handed down through generations; hence, no single person or social group holds the entire body of knowledge [31]. We set our confidence level at $95 \%$ and precision (margin of error) at $5 \%$ by using the sample-size calculator Raosoft (http:/ / www.raosoft.com/samplesize.html accessed on 4 February 2020). The total population size of the selected communities was approximately 6500 [32]. The number of respondents in each village/community in the KSNR ranged from 20-45, with a total of 363 respondents. Of these, 32 (19 women and 13 men) withdrew from the interview. These were removed from the analysis, producing a sample size of 331 households and a response rate of 91\%. We used semi-structured interview questionnaires involving closed and open-ended questions. Our questionnaires were based on a previous survey of perceptions of illegal hunting in southeastern Zimbabwe [33]. We constructed the questions to gather information on the socio-economic and demographic characteristics of respondents and their knowledge and perceptions of illegal hunting practices in the KSNR between 2006 and 2017.

Data collected included information on the frequency of sighting bushmeat and other wild animal products, perceptions of illegal hunting trends, hunting equipment, animal species hunted, and reasons for hunting (see Appendix A for questionnaires). Respondents indicated how frequently they saw bushmeat and other wild animal products, i.e., "every day", "once in 14 days", "once in 30 days", "once in 1-3 months", "once in 3-12 months", and "never seen it". Further, we asked respondents to rate the prevalence and trends of illegal hunting activities on a 5-point Likert scale ranging from "decrease greatly" (1) to "increase greatly" (5).

The questionnaires were translated from English to Twi by the first two authors of this article, and four undergraduate students were hired and trained to assist in the data collection. We pre-tested the questionnaires by interviewing five persons each in two communities outside our study zone in early August 2018, to assess the clarity of the questions. All interviews lasted between 30 and $70 \mathrm{~min}$. We thoroughly explained the purpose of the research to the respondents and obtained their consent to participate [34] after appropriate permission was obtained from the village heads. We explained that all 
interviews were anonymous and confidential and that they would not be at any risk in answering the questions. In all 18 villages, the research team also had more informal discussions with the village heads/leaders about the contents of the questionnaire, to gain additional qualitative information that could support the questionnaire data. We used tape recorders to record all the discussions with the full consent of the respondents.

To avoid or minimize a social bias towards questions targeting the topic of illegal activities (see, e.g., [35,36]) or a common method bias, e.g., [37], we implemented diverse methodological approaches during the interviews, such as decreasing the respondent's concerns about admitting to or sharing views on illegal hunting activities by emphasizing the anonymity, importance, and scientific character of the survey, and by adjusting the survey environment, i.e., ensuring bystanders were not present, e.g., [38]. To validate the information obtained from the local communities, we used the ranger-based monitoring data presented in the Section 4. The information from the ranger-based monitoring data was obtained from previous research [9] between 2006 and 2017 and complemented by information from the year 2018.

\subsection{Data Analyses}

To illustrate the open-ended questions, respondents quotes are presented verbatim unless otherwise stated. To protect the identity of the respondents we used unique identifier codes for each respondent, with each respondent code indicating the sequence of the interviews (e.g., a respondent who was our 16th interviewee was given a unique code of R016).

All percentages were calculated based on the total number of respondents in the sampled communities. However, for multiple responses on an open-response question, we presented the data as the percentage of the respondents giving each response, and these may sum to over $100 \%$.

To determine the differences in the knowledge and perception of commonly used hunting equipment between communities inside and outside the park, we also used the chi-square $\left(\chi^{2}\right)$ test. To determine the relationship between the socio-demographic characteristics of respondents and their perception of the prevalence and trends in illegal hunting activities, we used an ordinal logistic regression model. The independent variables included in the model were gender, education, occupation, and location of the communities (inside vs. outside) as factors, and age and length of residence as covariates [39]. We performed a post hoc test to test for a potential common method bias in our interviews, specifically Harman's single-factor test [37]. We used SPSS version 27 (SPSS, Inc, Chicago, IL, USA) for all statistical analyses, with the level of significance set at $p \leq 0.05$.

\section{Results}

Forty-six percent $(n=153)$ and $54 \%(n=178)$ of respondents lived inside and outside the park, respectively. In total, $60 \%$ were males $(n=198)$, while $40 \%$ were females $(n=133)$. However, the gender balance was almost the same for respondents living outside the park as for residents inside the park (Table 1). Half of the respondents were married $(n=165)$, and most were above the age of 36 years. The education of respondents was low; $36 \%$ had no education, while $27 \%$ had only primary education. Half of the respondents were farmers $(n=166)$, and very few of them were unemployed $(n=15)$. The average household size consisted of two adults and three to five children. Most respondents, $68.6 \%$ $(n=227)$, had lived in the area for $\geq 11$ years. Table 1 provides details of the respondents' socio-demographic information. 
Table 1. Socio-demographic characteristics of respondents living inside and outside the KSNR.

\begin{tabular}{|c|c|c|c|c|c|c|}
\hline \multirow{2}{*}{ Categories } & \multicolumn{2}{|c|}{ Inside } & \multicolumn{2}{|c|}{ Outside } & \multicolumn{2}{|c|}{ Total } \\
\hline & Frequency & Percent (\%) & Frequency & Percent (\%) & Frequency & Percent (\%) \\
\hline \multicolumn{7}{|l|}{ Gender } \\
\hline Male & 103 & 67 & 95 & 53 & 198 & 60 \\
\hline Female & 50 & 33 & 83 & 47 & 133 & 40 \\
\hline \multicolumn{7}{|l|}{ Age (years) } \\
\hline $18-25$ & 7 & 4 & 10 & 5 & 17 & 5 \\
\hline $26-35$ & 33 & 22 & 33 & 18 & 66 & 20 \\
\hline $36-45$ & 31 & 20 & 49 & 28 & 80 & 24 \\
\hline $46-55$ & 47 & 31 & 49 & 28 & 96 & 29 \\
\hline 56 and above & 35 & 23 & 37 & 21 & 72 & 22 \\
\hline \multicolumn{7}{|l|}{ Marital status } \\
\hline Single & 37 & 24 & 61 & 34 & 98 & 30 \\
\hline Married & 81 & 53 & 84 & 47 & 165 & 50 \\
\hline Divorced & 35 & 23 & 33 & 19 & 68 & 20 \\
\hline \multicolumn{7}{|l|}{ Education } \\
\hline No education & 63 & 41 & 55 & 31 & 118 & 36 \\
\hline Primary education & 33 & 22 & 58 & 33 & 91 & 28 \\
\hline Junior secondary & 34 & 22 & 51 & 29 & 85 & 25 \\
\hline Senior Secondary & 15 & 10 & 10 & 5 & 25 & 8 \\
\hline Tertiary & 8 & 5 & 4 & 2 & 12 & 3 \\
\hline \multicolumn{7}{|l|}{ Occupation } \\
\hline Farming & 72 & 47 & 94 & 53 & 166 & 50 \\
\hline Livestock keeping & 18 & 12 & 17 & 9 & 35 & 10 \\
\hline $\begin{array}{c}\text { Charcoal } \\
\text { production/selling }\end{array}$ & 27 & 18 & 23 & 13 & 50 & 15 \\
\hline Hunting & 11 & 7 & 14 & 8 & 25 & 7 \\
\hline Employment/business & 17 & 11 & 23 & 13 & 40 & 13 \\
\hline Unemployed & 8 & 5 & 7 & 4 & 15 & 5 \\
\hline \multicolumn{7}{|l|}{ Household size } \\
\hline 0 & 22 & 14 & 53 & 30 & 75 & 23 \\
\hline $1-2$ & 32 & 21 & 50 & 28 & 82 & 25 \\
\hline $3-5$ & 60 & 39 & 67 & 38 & 127 & 38 \\
\hline 6 and above & 39 & 26 & 8 & 4 & 47 & 14 \\
\hline \multicolumn{7}{|l|}{ Length of residence (years) } \\
\hline $1-5$ & 13 & 9 & 25 & 14 & 38 & 12 \\
\hline $6-10$ & 45 & 29 & 21 & 12 & 66 & 20 \\
\hline 11 and above & 95 & 62 & 132 & 74 & 227 & 69 \\
\hline
\end{tabular}

\subsection{Perceptions about Prevalence and Long-Term Trends in Illegal Hunting Activities}

More respondents living inside the park reported sighting bushmeat and other wildlife products frequently than those outside, over the years (Figure 2). Twenty-three percent $(n=35)$ and $7 \%(n=11)$ of respondents living inside and outside the park, respectively, reported sighting bushmeat and other wildlife products every day. Similarly, the majority of respondents $(n=64,19 \%)$ who perceived an increase in illegal hunting activities over the years lived inside the park with only a few $(n=20,6 \%)$ of those living outside the park reporting an increase (Figure 3 ). However, of the total number of respondents who perceived a decrease in illegal hunting activities, the majority $(n=139,42 \%)$ were residents living outside the park, while $16 \%(n=53)$ lived inside the park. In addition, $36(11 \%)$ and $19(6 \%)$ respondents living inside and outside the park, respectively, reported no change in illegal hunting activities over the years. 


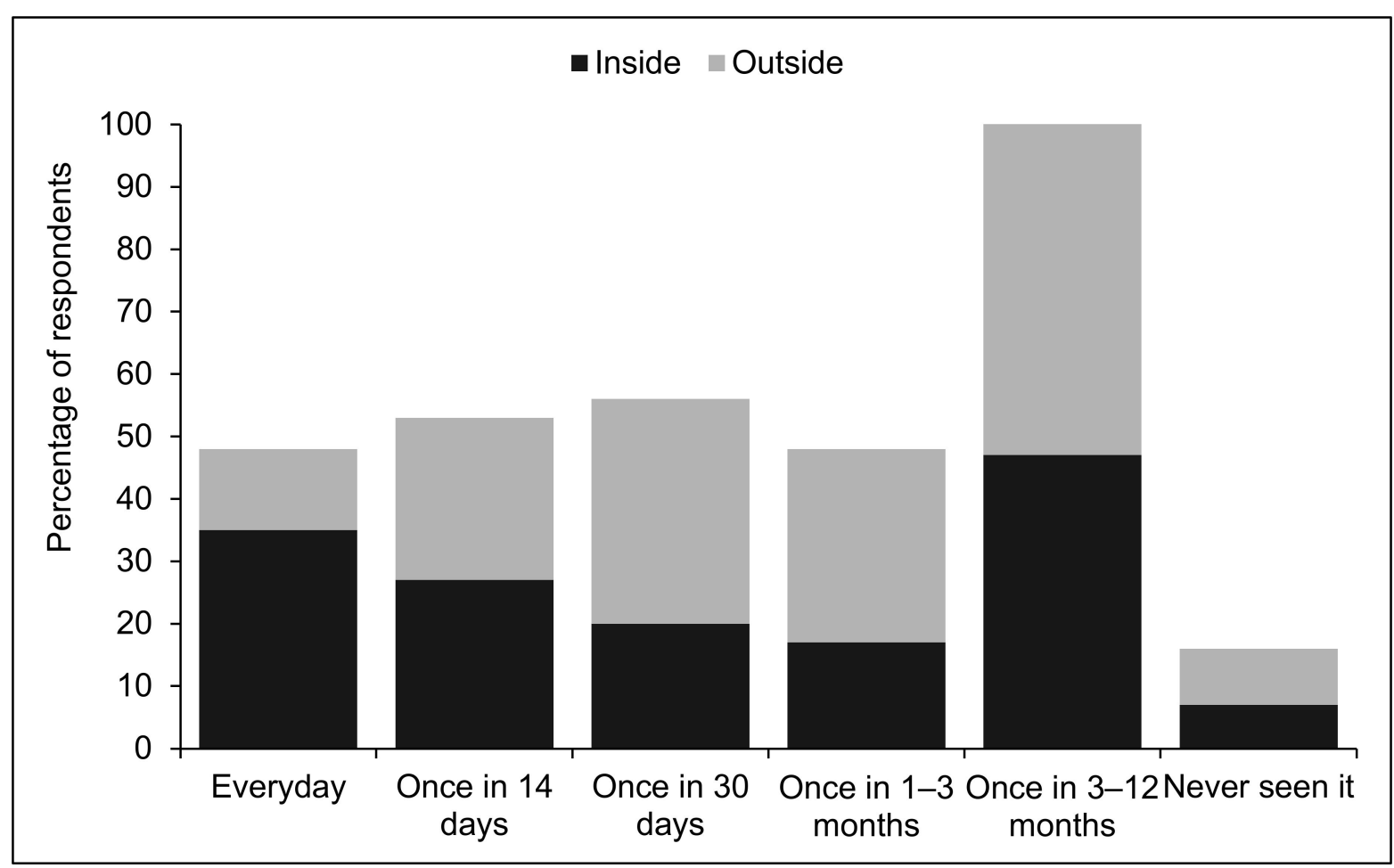

Figure 2. Perception of respondents about the frequency of sighting bushmeat/wildlife products. The total number of respondents living inside and outside the park was 153 and 178, respectively.

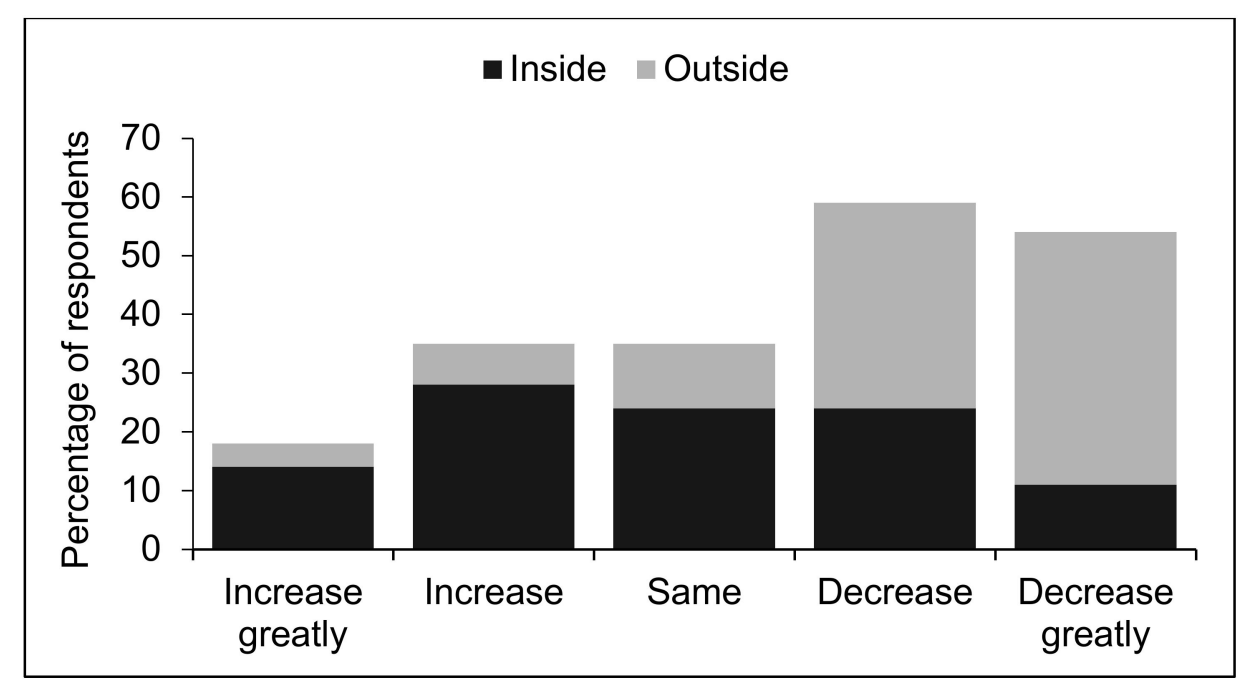

Figure 3. The perceived trends of illegal hunting activities between 2006 and 2017. The total number of respondents living inside and outside the park was 153 and 178, respectively.

The reasons given for a perceived increase in illegal hunting (Figure 4a) were: (i) the high influx of migrants leading to human population increase; (ii) retaliatory killings related to crop damage. 


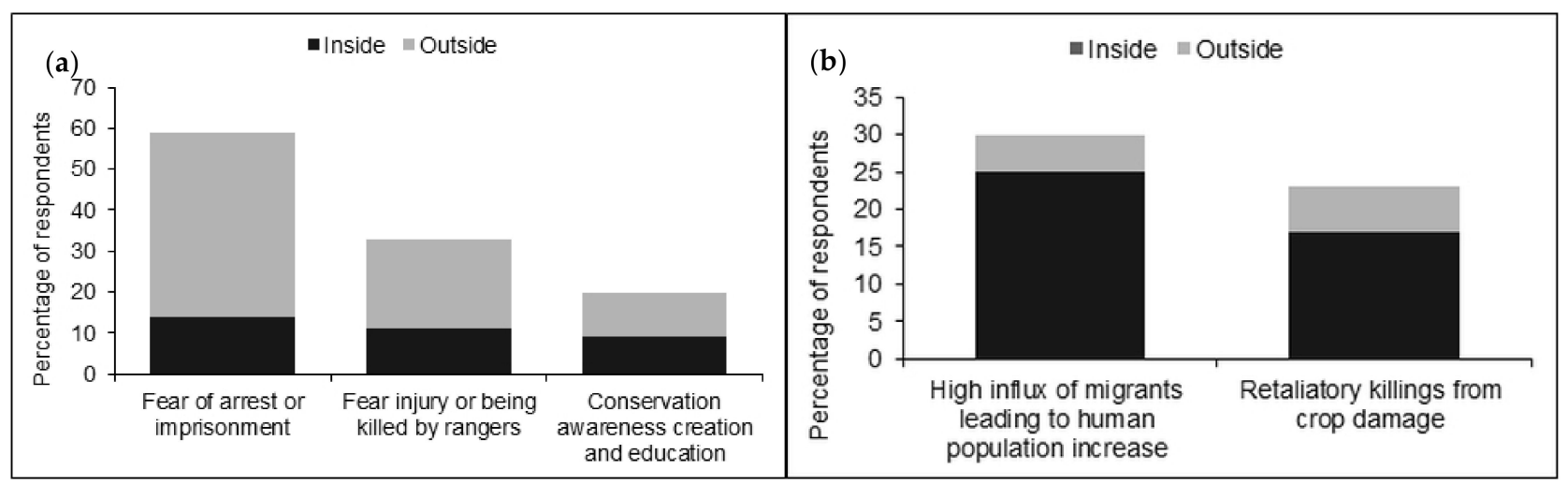

Figure 4. Reasons for the perceived (a) increasing and (b) decreasing trends in illegal hunting activities in Kogyae Strict Nature Reserve from 2006 to 2017. The total number of respondents living inside and outside the park was 153 and 178 , respectively.

One respondent said that:

"So many people (migrants) have moved into the park and surrounding villages in search of fertile lands to farm and better living conditions. Together with the indigenes have increased human population which has put too much pressure on the park including illegal hunting activities".

On the other hand, the main reasons given for a perceived decrease in illegal hunting activities (Figure 4b) included: (i) illegal hunters fear arrest and imprisonment by the authorities; (ii) illegal hunters fear injury or being killed by law enforcement rangers; (iii) wildlife conservation awareness creation. Specifically, respondent R016 reported that:

"I have my family to take care of and so I will not risk going hunting and get arrested".

In addition, respondent R054 said:

"If I get arrested now by hunting ... who will bail me? Nobody. My family is poor and we have no connections (no friends at the judiciary or the top-level) to ask for help".

Other respondents such as R032, R115, R207, and R294 were of a similar view:

"I (we) hear that conditions in the prisons (Ghana prisons) are bad, so why will I (we) go hunting and get imprisoned just for common meat or money? I (we) will rather starve than go hunting".

Similarly, respondents R005, R009, R81, R93, R213, and R306 expressed their anxiety about encountering law enforcement rangers during hunting:

"I (we) may encounter them and exchange fire (especially when using firearms) and you may be injured or killed".

Further, R101 confirmed that:

"In truth, I was nearly killed when I went hunting some time ago. I gave a warning shot to scare the rangers away, but I was shot at, and I had to run away to escape death and or arrest. I promised myself that I will never go hunting again and will also not advise anyone to do so".

Respondents also highlighted that wildlife conservation awareness was one of the reasons for the declining trend in illegal hunting activities. For example, R157 described how law enforcement rangers and other park authorities continue to educate them on wildlife conservation:

"Anytime they come here and speak to us about the importance of conserving the animals in the park".

Respondent R321 also confirmed that: 
"At first, I thought hunting was our right and a source of food/income, but after continuous awareness creation, I now know about the importance of wildife conservation".

3.2. Effects of Socio-Demographic Factors on the Perception of Local Communities about Illegal Hunting Activities

The model testing the effects of socio-demographic factors on the frequency of sighting bushmeat and other wild animal products, indicated the significant improvement of the model relative to the baseline null model (likelihood ratio $\chi^{2}=119, \mathrm{df}=13, p<0.001$ ), while a goodness-of-fit test indicated that the model was not good (Pearson $\chi^{2}=1313, \mathrm{df}=1172$, $p=0.002$ ). A possible reason for this was that among the six predictors, only gender and the location of the communities significantly predicted the frequency of sighting bushmeat and other wildlife products. The odds ratio indicated that local community members living inside the park were 2.6 times more likely to see bushmeat and other wildlife products than those living outside. Furthermore, men were 0.1 times less likely to see bushmeat and other wildlife products than women (Table 2). Nagelkerke's $R^{2}$ explained $31 \%$ of the variation between genders, the location of communities, and the frequency of sighting bushmeat and other wildlife products.

Table 2. Effects of local communities' socio-demographic factors on the frequency of sighting bushmeat and other wildlife products in KSNR.

\begin{tabular}{|c|c|c|c|c|c|c|c|c|}
\hline \multirow{2}{*}{ Variables } & \multirow{2}{*}{ Estimate } & \multirow{2}{*}{ Std. Error } & \multirow{2}{*}{ Wald } & \multirow{2}{*}{ df } & \multirow{2}{*}{ Sig. } & \multicolumn{3}{|c|}{$95 \%$ Confidence Interval } \\
\hline & & & & & & Lower Bound & Odds Ratio & Upper Bound \\
\hline Age (years) & -0.070 & 0.087 & 0.637 & 1 & 0.425 & -0.241 & 0.933 & 0.101 \\
\hline Length of residence (years) & -0.216 & 0.149 & 2.092 & 1 & 0.148 & -0.509 & 0.806 & 0.077 \\
\hline \multicolumn{9}{|l|}{ Gender } \\
\hline Male & -2.162 & 0.237 & 83.409 & 1 & 0.000 & -2.626 & 0.115 & -1.698 \\
\hline Female & $0^{\mathrm{a}}$ & & & 0 & & & 1 & - \\
\hline \multicolumn{9}{|l|}{ Education } \\
\hline No formal & 0.682 & 0.570 & 1.434 & 1 & 0.231 & -0.434 & 1.978 & 1.799 \\
\hline Primary & 0.733 & 0.580 & 1.601 & 1 & 0.206 & -0.403 & 2.082 & 1.870 \\
\hline Junior secondary & 0.693 & 0.582 & 1.420 & 1 & 0.233 & -0.447 & 2.001 & 1.834 \\
\hline Senior secondary & 0.575 & 0.661 & 0.756 & 1 & 0.385 & -0.721 & 1.777 & 1.870 \\
\hline Tertiary & $0^{\mathrm{a}}$ & & & 0 & & . & 1 & - \\
\hline \multicolumn{9}{|l|}{ Occupation } \\
\hline Farming & -1.406 & 0.519 & 7.345 & 1 & 0.077 & -2.422 & 0.245 & -0.389 \\
\hline Livestock keeping & -1.226 & 0.586 & 4.375 & 1 & 0.066 & -2.375 & 0.293 & -0.077 \\
\hline Charcoal production/selling & -0.648 & 0.564 & 1.323 & 1 & 0.250 & -1.753 & 0.523 & 0.456 \\
\hline Hunting & -0.693 & 0.624 & 1.236 & 1 & 0.266 & -1.916 & 0.500 & 0.529 \\
\hline Business/formal employment & -1.604 & 0.584 & 7.553 & 1 & 0.086 & -2.749 & 0.201 & -0.460 \\
\hline Unemployed & $0^{\mathrm{a}}$ & & & 0 & & . & 1 & . \\
\hline \multicolumn{9}{|l|}{ Location of community } \\
\hline Inside & 0.975 & 0.215 & 20.643 & 1 & 0.000 & 0.555 & 2.652 & 1.396 \\
\hline Outside & $0^{\mathrm{a}}$ & . & 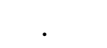 & 0 & . & & & \\
\hline
\end{tabular}

a Set to zero because this parameter is redundant.

The model testing the effects of socio-demographic factors on perceptions and knowledge of the trends in illegal hunting activities indicated a significantly good fit in both tests, for the model fitting relative to the null model (likelihood ratio $\chi^{2}=118$, $\mathrm{df}=13$, $p<0.001$ ) and the goodness-of-fit test (Pearson $\chi^{2}=917, \mathrm{df}=935, p=0.65$ ). The location of the communities, length of residence, and gender significantly predicted the respondents perception and knowledge of the trends in illegal hunting activities (Table 3). The odds ratio indicated that respondents who lived outside the park were 7 times more likely to perceive decreasing trends in illegal hunting activities. Residents who had lived longer in the area were 0.7 times more likely to perceive decreasing trends in illegal hunting activities than short- to medium-term residents, and men were 0.3 times more likely to perceive 
decreasing trends in illegal hunting activities than females. Nagelkerke's $\mathrm{R}^{2}$ indicated that the model explained $32 \%$ of the variation in the results.

Table 3. Effects of local communities' socio-demographic factors on the knowledge and perceptions of the trends in illegal hunting activities in KSNR.

\begin{tabular}{|c|c|c|c|c|c|c|c|c|}
\hline \multirow{2}{*}{ Variables } & \multirow{2}{*}{ Estimate } & \multirow{2}{*}{ Std. Error } & \multirow{2}{*}{ Wald } & \multirow{2}{*}{ df } & \multirow{2}{*}{ Sig. } & \multicolumn{3}{|c|}{$95 \%$ Confidence Interval } \\
\hline & & & & & & Lower Bound & Odds Ratio & Upper Bound \\
\hline Age (years) & 0.047 & 0.088 & 0.292 & 1 & 0.589 & -0.125 & 1.049 & 0.220 \\
\hline Length of residence (years) & -0.335 & 0.150 & 5.002 & 1 & 0.025 & -0.629 & 0.715 & -0.041 \\
\hline \multicolumn{9}{|l|}{ Gender } \\
\hline Male & -1.039 & 0.220 & 22.396 & 1 & 0.000 & -1.470 & 0.354 & -0.609 \\
\hline Female & $0^{\mathrm{a}}$ & 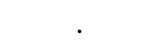 & . & 0 & . & & 1 & \\
\hline \multicolumn{9}{|l|}{ Education } \\
\hline No formal & -0.730 & 0.555 & 1.731 & 1 & 0.188 & -1.817 & 0.482 & 0.357 \\
\hline Primary & -0.534 & 0.564 & 0.895 & 1 & 0.344 & -1.640 & 0.586 & 0.572 \\
\hline Junior secondary & -1.118 & 0.570 & 3.847 & 1 & 0.060 & -2.235 & 0.327 & -0.001 \\
\hline Senior secondary & -0.626 & 0.647 & 0.936 & 1 & 0.333 & -1.894 & 0.535 & 0.642 \\
\hline Tertiary & $0^{\mathrm{a}}$ & . & . & 0 & . & & 1 & \\
\hline \multicolumn{9}{|l|}{ Occupation } \\
\hline Farming & -0.218 & 0.501 & 0.190 & 1 & 0.663 & -1.200 & 0.804 & 0.764 \\
\hline Livestock keeping & 0.444 & 0.571 & 0.606 & 1 & 0.436 & -0.674 & 1.559 & 1.562 \\
\hline Charcoal production/selling & 0.027 & 0.549 & 0.002 & 1 & 0.960 & -1.049 & 1.028 & 1.104 \\
\hline Hunting & -0.433 & 0.624 & 0.483 & 1 & 0.487 & -1.656 & 0.648 & 0.789 \\
\hline Business/formal employment & -0.566 & 0.570 & 0.986 & 1 & 0.321 & -1.684 & 0.568 & 0.551 \\
\hline Unemployed & $0^{a}$ & & & 0 & & & 1 & \\
\hline \multicolumn{9}{|l|}{ Location of community } \\
\hline Inside & 1.984 & 0.231 & 73.793 & 1 & 0.000 & 1.531 & 7.271 & 2.437 \\
\hline Outside & $0^{\mathrm{a}}$ & & & 0 & & & 1 & \\
\hline
\end{tabular}

${ }^{\text {a }}$ Set to zero because this parameter is redundant.

Harman's single-factor test showed $12 \%$ of the variance in extraction sums of squared loadings and did not confirm any common method bias in our interviews, as $>50 \%$ of the variance is considered as an indicator of common method bias.

\subsection{Hunting Equipment, Hunted Animal Species, and Reasons for Hunting}

There was no significant difference between respondents living inside and outside the park regarding their perception of the equipment and methods used for hunting $\left(\chi^{2}=4.1\right.$, $\mathrm{df}=3, p=0.3)$. Most of the respondents reported that snares $(n=231,70 \%)$ and firearms $(n=73,22 \%)$ were the most common forms of hunting equipment and methods used in the area (Table 4$)$. These were mostly used to hunt grasscutters $(n=143,43 \%)$, bushbucks $(n=64,19 \%)$, duikers $(n=46,14 \%)$, kobs $(n=37,11 \%)$, buffalo $(n=19,6 \%)$, pangolins $(n=13,4 \%)$, and patas monkeys $(n=9,3 \%)$.

Table 4. Local communities' knowledge of hunting equipment and methods used in Kogyae Strict Nature Reserve.

\begin{tabular}{cccccc}
\hline \multirow{2}{*}{ Hunting Equipment/Method } & \multicolumn{2}{c}{ Location of Community } & \multicolumn{3}{c}{ Statistics } \\
\cline { 2 - 5 } & Inside (\%) & Outside (\%) & $\chi^{2}$ & df & $p$ \\
\hline Snares & $115(75)$ & $116(65)$ & & & \\
Firearms & $27(18)$ & $46(26)$ & 4.1 & 3 & 0.3 \\
Bushfires & $7(4)$ & $11(6)$ & & & \\
Hunting with dogs & $4(3)$ & $5(3)$ & & & \\
\hline
\end{tabular}

The respondents highlighted various reasons why local communities hunt illegally: (i) trading of bushmeat to raise money $(n=237,72 \%)$; (ii) bushmeat for domestic consumption ( $n=182,55 \%$ ); (iii) hunting for traditional reasons ( $n=98,30 \%$ ); (iii) unemployment 
( $n=74,22 \%$ ); (iv) to minimize crop damage ( $n=71,21 \%$ ). For example, respondent R188 mentioned that:

"Most of the hunters I know go hunting because of money from the sale of bushmeat. Some of them and families may sleep without food if they do not get a catch and or a buyer".

Respondent R003 also explained that:

"The money he (they) get from the sale of bushmeat is better than selling your farm produce such as yam, cassava, and plantain. It is a good business but risky".

Other respondents such as R233 mentioned the fact that hunters hunt for consumption:

"My husband used to set traps in the park, but he only brings his catch for us to eat. We can eat this catch for more than a week".

Respondent R167 also reported that:

"Bushmeat is delicious than the livestock and poultry we eat here. I know that most of the hunters hunt especially grasscutter for domestic consumption".

Further, respondents explained that hunting occurs because people believe it is their right to hunt. R300 reported that:

"This land (park) belongs to us. We are custodians of the land and, as such, we must have full access to everything within it".

Other respondents also explained hunting occurs because those involved in it do not have jobs. R325 said that:

"My brother was a hunter because he had no job nor a land to farm on so, he chose hunting for survival".

Similarly, some respondents explained that they hunt because of retaliation for crop damage by some animals in the park. For example, R260 explained that:

"I (we) set traps in our farms to kill animals that damage our food crops especially... hmm ... that animal, "adwee" (patas monkey)".

\section{Discussion}

\subsection{Perceptions about Prevalence and Long-Term Trends in Illegal Hunting Activities}

Wildlife hunting is inevitably associated with the lives of local people, and bushmeat, wildlife products, and associated activities, i.e., hunting, were frequently present in local communities, despite the fact that there were some differences among particular groups of people.

The strongest factor influencing peoples' perceptions of bushmeat sightings and illegal hunting was living inside or outside the protected area. The residents living inside rely more for their livelihoods on bushmeat and wildlife products than the residents living outside, which may explain why their sightings of bushmeat were shifted towards daily or more frequent sightings, while the outside residents reported these sightings less frequently, i.e., with longer periods between sightings, especially between 3 and 12 months. Another possible reason for fewer sightings of bushmeat by those outside the protected area is that all the rangers' camps are located along the boundaries and in the villages adjacent to the KSNR. Outside villages are therefore rangers' bases and areas around them are starting points for law enforcement patrols, thus they are heavily patrolled by default. This substantially decreases the probability of occurrence of poaching-related events [40]. However, the communities inside the park may implicitly engage in increased bushmeat consumption and trade, and bushmeat may be more accessible, i.e., prices may be lower [41,42].

Living inside or outside the protected areas also strongly influenced the local communities' perceptions of long-term trends in illegal hunting activities. People living inside 
the KSNR reported trends that may be due to their more frequent use of bushmeat and other wildlife products. Additionally, residents living inside mentioned two specific reasons for the perceived increase, i.e., an influx of new incomers to their villages, thereby creating higher pressure on natural resources, specifically hunting, and a higher incidence of retaliatory killings, since living inside the park also leads to a higher frequency of crop damage by wildlife than living outside the park. The people living outside the KSNR mostly reported a decreasing trend in illegal hunting over time which corresponded to the long-term records of illegal hunting activities in the park recorded by the ranger-based monitoring system (Appendix B). Their perception, therefore, reflected the long-term effects of KSNR law enforcement and therefore additionally confirmed that local people's knowledge can have a valid relevance to protected area management, e.g., [21]. We may also infer that effective law enforcement, by creating awareness of the consequences of breaking established rules, and positively oriented biodiversity conservation awareness campaigns in local communities result in deterring illegal hunting activities. Finally, we cannot rule out the possibility that the decline in illegal hunting activities in the park has been due to animal population decline caused by the destruction of habitat from intensive human activities such as farming and logging [29].

Gender was the next important factor explaining differences in perceptions regarding bushmeat and illegal hunting, which are both associated with the division of labour in households. Females sighted bushmeat and other wildlife products more frequently than men, in agreement with other studies in Africa reporting that the daily activities of women are more focused on agricultural production and livelihood chores, including going to the market [43-45]. Thus, women have considerable knowledge of their environment, and hence their involvement in the wildlife monitoring process should be increasingly encouraged, since women are vital stakeholders in conservation [45]. On the other hand, almost $68 \%$ of respondents who reported a decline in illegal hunting activities were males, as only men are involved in hunting, and hence they are more likely to assess trends in illegal hunting activities accurately. Protected area managers must acknowledge that even small communities are not homogenous entities. Understanding gender differences in socio-ecological systems is fundamental to the proper planning and implementation of conservation activities.

We found that local people who had lived in the area for more than ten years were more knowledgeable about the trends in illegal hunting activities over the years than short-term residents. Short-term residents had come to the KSNR area as recent migrants, and they may not experience any strong attachment to the protected area, while long-term residents feel a certain ownership of the site, valuing local wildlife and natural environments [46,47]. Although interventions to combat illegal hunting activities need a range of components, the knowledge and perceptions of local communities are a complex yet vital feature. Protected area managers should therefore acknowledge all factors and implement an understanding of overall differences in groups of people and their perceptions of nature in proper planning and engagement in conservation activities, as a part of a holistic approach [48].

\subsection{Hunting Equipment, Hunted Animal Species, and Reasons for Hunting}

The local communities reported that the most common hunting method used was snaring; this was consistent with the KSNR ranger-based monitoring data [9] and is known to be widespread in other protected areas in Ghana [49] and elsewhere, e.g., the Queen Elizabeth Conservation Area, Uganda [50] or the Serengeti National Park, Tanzania [51]. The reason clearly lies in the fact that this technique is quiet, time-efficient, and less risky compared to the use of noisy firearms, and placing more snares maximizes the probability of hunting success. In addition to snares, firearms are used. Dogs are also used by hunters, specifically to bring wildlife to bay or to chase animals into holes, where they are killed with shotguns or cutlasses [52]. Furthermore, informal discussions revealed that hunters use fire to force animals out of their hideouts, particularly grasscutters (Thryonomys swinderianu), which is the most hunted species in the KSNR. Bush fires are considered to be the highest 
threat to conservation in the KSNR [29], though they are associated not only with hunting but also strongly with illegal livestock grazing, because herdsmen intentionally burn dried grass during the dry season to induce the early sprouting of fresh grass for their cattle. Bush fires can also result from the careless handling of fires by palm wine tappers, local gin distillers, farmers, and cigarette smokers.

Illegal hunters and consumers preferred a range of animal species, notably grasscutters, bushbucks, duikers, and kobs. These targeted and preferred species, especially grasscutters, follow the pattern recorded in other parts of Ghana and West Africa, while buffalo (Syncerus caffer), pangolins (Smutsia temminckii), and baboons (Papio anubis) were amongst the least-targeted species, similarly to previous reports [53,54].

Drivers for the hunting of wildlife in the KSNR were similar to those in other regions of the world, specifically economic, nutritional, cultural, and recreational requirements [16,55]. The reasons given for illegal hunting in the present study suggest that the main drivers for bushmeat hunting include the need for money, need for food, unemployment, and retaliatory killing as a response to crop damage without compensation measures from the park management. These findings support previous research recognizing that the poverty of residents [56], inadequate livelihood sources [57,58], and a lack of alternative livelihoods [59] influence local people's decision to participate in risky illegal activities. Therefore, addressing the socio-economic livelihood needs and challenges of communities $[60,61]$ through the provision of alternative income streams, employment, and integrated conservation and development projects is vital in ensuring effective protected area management. Recent studies suggest that when communities benefit from protected areas, they are more likely and willing to protect the park and reduce engagement in illegal activities $[36,62]$.

\subsection{Integrating Local Community Knowledge into Protected Area Management}

The present study highlighted that local communities are knowledgeable about ecological processes and, more importantly, are familiar with the prevalence and trends of illegal hunting activities, which can provide valuable information for the management of the protected area. Information on the types of equipment used in hunting (some not captured by the ranger-based monitoring data) and motivations for hunting provide a clearer understanding for protected area managers and governments to underpin better conservation strategies. Conservationists, however, do not usually integrate local knowledge, which is often qualitative, in a non-standard format, and different from their own [63], despite the fact that local communities' knowledge has been effective and efficient in monitoring the hunting of vulnerable tropical forest species at large scales. For instance, Parry and Peres [64] found through interviews with local people that hunting led to the depletion of threatened species from large areas of their putative ranges, even in the 1.6 million $\mathrm{km}^{2}$ Brazilian State of Amazonas, where primary forests are still intact. As protected area management evolves, current perceptions about local communities' knowledge and the role of these communities in conservation need to change. Local communities' knowledge may not only fill scientific knowledge gaps but may also contribute to higher success in protected area management by making local resource users feel important and included in the process. Carmack and Macdonald [65] argued that where the focus and the scale of inquiry are the same, collaborative research should regard scientific and local communities' knowledge as equal. The integration of local communities' knowledge into protected area policy and management decision processes is of importance in Africa and many developing countries, where many local communities still rely on PA resources for their subsistence. Local community knowledge could be a vital stronghold for their livelihoods as well as for the survival of their culture.

\section{Conclusions}

Understanding the knowledge and perceptions of local people about protected areas and the activities within them represents a vital source of information for conservation man- 
agers [21,66], and a tool for improving relationships between communities and protected area management [67].

When considering complex ecological systems, it is uncommon to have a study with objective data on human behaviour. In this study, the combination of different data sources improved its internal and external validity, especially with regard to sensitive items. Local communities' knowledge and perceptions of trends in illegal hunting activities were inconsonant with the long-term ranger-based monitoring data. Perceptions of bushmeat sightings and illegal hunting trends were influenced by living inside or outside the protected area, gender, and residence time. Residents living inside perceived bushmeat and hunting as frequently present in their environment, while people living adjacent to the KSNR were more knowledgeable about decreasing bushmeat and illegal hunting trends.

Furthermore, the local communities perceived that snares were the most common hunting equipment used, and this was consistent with the ranger-based monitoring data. The reasons given for hunting illegally included the need for money, bushmeat, unemployment, and retaliatory killings This information should provide a good basis for developing measures that diversify sources of income for local communities, and these measures are likely to result in a reduction in illegal hunting. Effective responses will require relating illegal wildlife hunting to development rather than solely to conservation. Similarly, acknowledging the diversity of local communities in their perceptions within their social, economic, cultural, and environmental backgrounds is the way to target effective educational programmes and environmental awareness campaigns to enhance community knowledge and people's involvement in wildlife conservation. Such initiatives should provide opportunities for people to become involved in wildlife conservation as peer educators and should empower local communities in actions aimed at protecting biodiversity.

Our findings indicate that recognition of local communities' knowledge and perceptions by protected area authorities may substantially assist in developing effective conservation strategies and overall improvement of the local socio-ecological systems.

Author Contributions: Conceptualization, J.O.A. and P.H.; methodology, data collection, and analyses, J.O.A. and M.O.A.; writing—original draft preparation, J.O.A. and M.O.A.; writing-review and editing, P.H. All authors have read and agreed to the published version of the manuscript.

Funding: This research was funded by the CZECH UNIVERSITY OF LIFE SCIENCES PRAGUE, grant numbers CIGA20185007 and IGA20213103, and PH was funded by the MINISTRY OF EDUCATION, YOUTH AND SPORTS, Czechia, grant number CZ.02.2.69/0.0/0.0/19_074/0016295.

Institutional Review Board Statement: Research approval and permits were granted by the Wildlife Division of the Forestry Commission of Ghana (permit number WD/A.30/VOL. 11/28).

Informed Consent Statement: Informed consent was obtained from all subjects involved in the study.

Data Availability Statement: The data presented in this study are available on request from the corresponding author.

Acknowledgments: The authors acknowledge the Wildlife Division of Ghana for their permission and assistance during the data collection.

Conflicts of Interest: The authors declare no conflict of interest.

\section{Appendix A}

Interview questionnaire on understanding local communities' knowledge and perception about illegal hunting activities. Introduction

Thank you so much for meeting me. I appreciate your time. This should take about half an hour to an hour. Would you mind if I audio record this meeting so that I can make sure that I don't miss anything important that you tell me? Despite being taped, I would like to assure you that the transcribed notes will contain no information that would link you to specific statements. The information from our discussion today will be anonymous. Do you have any questions or concerns so far?. Okay great! Let's get started:

Date: 
Time:

Interview reference number:

Village name:

Village location: $\square$ Inside $\square$ Outside

\section{Basic information}

1.1 Name (optional):

1.2 Gender: $\square$ Male $\square$ Female

1.3 Age: $\square$ 18-25 $\square$ 26-35 $\square$ 36-45 $\square$ 46-55 $\square>55$

1.4 Marital status: $\square$ Single $\square$ Married

1.5 Education: $\square$ No formal $\square$ Primary $\square$ Junior Secondary $\square$ Senior Secondary $\square$ Tertiary

1.6 Occupation: $\square$ Farming $\square$ Livestock keeping $\square$ Charcoal production/selling $\square$ Hunting

$\square$ Employment/business $\square$ Unemployed

1.7 Household size: $\square$ 1-2 $\square$ 3-5 $\square>5$

1.8 Length of residence: $\square 1-5 \square 6-10 \square>10$

2.1 How often do you see bushmeat and other wildlife products in your village?

$\square$ Every day $\square$ Once in 14 days $\square$ Once in 30 days $\square$ Once in 1-3 months

$\square$ Once in 3-12 months $\square$ Never seen it.

2.2 In your opinion what are the trends in illegal hunting activities over the past 18 years?

$\square$ Increase greatly $\square$ Increase $\square$ Same $\square$ Decrease $\square$ Decrease greatly

2.3 What are the reasons for the given trend in illegal hunting activities in the area?

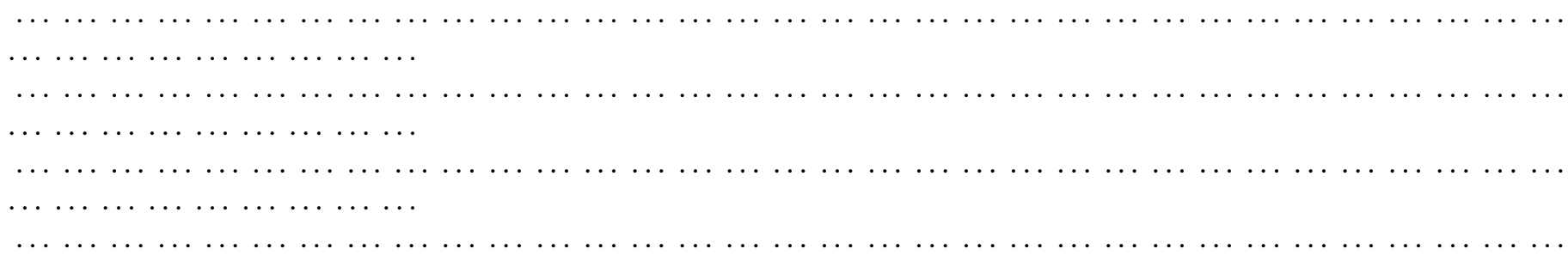

2.4 What are the common illegal hunting equipment used in the area?

2.5 May you list the wild animal species that are mostly hunted illegally in the area?

2.6 In your opinion what are the main reasons why people engage in illegal hunting activities in the area?

\section{Conclusion}


Thank you for the time and information that you have shared with me today! This has been a very interesting meeting and your opinions will be really valuable. Once again, I would like to remind you that any comments of yours will be anonymous.

\section{Appendix B}

Table A1. Actual trends in prevalence and distribution of illegal hunting activities in KSNR (2006-2018).

\begin{tabular}{|c|c|c|c|c|c|c|c|c|c|c|c|c|c|c|c|c|c|}
\hline $\begin{array}{l}\text { Illegal Hunting } \\
\text { Activities }\end{array}$ & 2006 & 2007 & 2008 & 2009 & 2010 & 2011 & 2012 & 2013 & 2014 & 2015 & 2016 & 2017 & 2018 & $\begin{array}{c}\text { Total } \\
\text { Incidents }\end{array}$ & $\%$ & Avg/yr & $\underset{\mathbf{k m}^{2}}{\text { Incident/ }}$ \\
\hline $\begin{array}{l}\text { Poachers } \\
\text { arrested }\end{array}$ & 6 & 11 & 9 & 9 & 11 & 11 & 10 & 7 & 6 & 12 & 12 & 3 & 3 & 110 & 4 & 8.5 & 0.3 \\
\hline $\begin{array}{l}\text { Poachers } \\
\text { observed }\end{array}$ & 28 & 10 & 32 & 126 & 65 & 45 & 2 & 25 & 5 & 2 & 15 & 5 & 1 & 361 & 13.1 & 27.8 & 1 \\
\hline $\begin{array}{l}\text { Poacher's camps } \\
\text { found }\end{array}$ & 28 & 12 & 16 & 38 & 33 & 12 & 1 & 4 & 13 & 6 & 2 & 2 & 2 & 169 & 6.1 & 13 & 0.5 \\
\hline Gunshots heard & 80 & 76 & 69 & 98 & 153 & 67 & 12 & 16 & 47 & 59 & 38 & 33 & 26 & 774 & 28 & 59.5 & 2.1 \\
\hline $\begin{array}{l}\text { Firearms } \\
\text { confiscated }\end{array}$ & 5 & 5 & 5 & 5 & 32 & 6 & 8 & 9 & 5 & 10 & 7 & 4 & 2 & 103 & 3.7 & 7.9 & 0.3 \\
\hline Snares found & 70 & 68 & 194 & 218 & 217 & 41 & 47 & 53 & 34 & 39 & 61 & 44 & 9 & 1095 & 39.6 & 84.2 & 3 \\
\hline $\begin{array}{l}\text { Animals found } \\
\text { killed }\end{array}$ & 10 & 6 & 7 & 29 & 57 & 19 & 2 & 5 & 6 & 4 & 6 & 1 & 1 & 153 & 5.5 & 11.8 & 0.02 \\
\hline Total & 227 & 188 & 332 & 523 & 568 & 201 & 82 & 119 & 116 & 132 & 141 & 92 & 44 & 2765 & 100 & & \\
\hline
\end{tabular}

\section{References}

1. Bowen-Jones, E.; Brown, D.; Robinson, E. Economic commodity of environmental crisis? An interdisciplinary approach to analysing the bushmeat trade in Central and West Africa. Area 2003, 35, 390-402. [CrossRef]

2. Milner-Gulland, E.J.; Bennet, E.L.; Group, S.A.C.W.M. Wild meat-the bigger picture. Trends Ecol. Evol. 2003, 18, 351-357. [CrossRef]

3. Nielsen, M.R. Importance, cause, and effect of bushmeat hunting in the Udzungwa Mountains, Tanzania: Implications for community-based wildlife management. Biol. Conserv. 2006, 128, 509-516. [CrossRef]

4. Covey, R.; Scott McGraw, W. Monkeys in a West African Bushmeat Market: Implications for Cercopithecid Conservation in Eastern Liberia. Trop. Conserv. Sci. 2014, 7, 115-125. [CrossRef]

5. Van Velden, J.; Wilson, K.; Biggs, D. The evidence for the bushmeat crisis in African savannas: A systematic quantitative literature review. Biol. Conserv. 2018, 221, 345-356. [CrossRef]

6. Kümpel, N.F.; Rowcliffe, J.M.; Cowlishaw, G.; Milner-Gulland, E.J. Trapper Profiles and Strategies: Insights into Sustainability from Hunter Behaviour. Anim. Conserv. 2009, 12, 531. [CrossRef]

7. Tumusiime, D.M.; Eilu, G.; Tweheyo, M.; Babweteera, F. Wildlife Snaring in Budongo Forest Reserve, Uganda. Human Dimen. Wildl. 2010, 15, 129-144. [CrossRef]

8. Rowcliffe, J.M.; de Merode, E.; Cowlishaw, G. Do wildlife laws work? Species protection and the application of a prey choice model to poaching decisions. Proc. R. Soc. B Biol Sci. 2004, 271, 2631-2636. [CrossRef]

9. Afriyie, J.; Asare, M.; Osei-Mensah, J.; Hejcmanová, P. Evaluation of long-term law enforcement monitoring in a West African protected area. Oryx 2021, 55, 732-738. [CrossRef]

10. Loibooki, M.; Hofer, H.; Campbell, K.L.I.; East, M.L. Bushmeat hunting by communities adjacent to the Serengeti National Park, Tanzania: The importance of livestock ownership and alternative sources of protein and income. Environ. Conserv. 2002, 29, 391-398. [CrossRef]

11. Metzger, K.L.; Sinclair, A.R.E.; Hilborn, R.; Hopcraft, J.G.C.; Mduma, S.A.R. Evaluating the protection of wildlife in parks: The case of African buffalo in Serengeti. Biodivers. Conserv. 2010, 19, 3431-3444. [CrossRef]

12. Newmark, W.D. Isolation of African protected areas. Front. Ecol. Environ. 2008, 6, 321-328. [CrossRef]

13. Wilfred, P.; MacColl, A.D.C. Income sources and their relation to wildlife poaching in Ugalla ecosystem, Western Tanzania. Afr. J. Environ. Sci. Tech. 2010, 4, 886-896.

14. Johannesen, A.B. Designing integrated conservation and development projects (ICDPs): Illegal hunting, wildlife conservation, and the welfare of the local people. Environ. Dev. Econ. 2006, 11, 247-267. [CrossRef]

15. Holmern, T.; Mkama, S.; Muya, J.; Røskaft, E. Intraspecific prey choice of bushmeat hunters outside the Serengeti National Park, Tanzania: A preliminary analysis. Afr. Zool. 2006, 41, 81-87. [CrossRef]

16. Bitanyi, S.; Nesje, M.; Kusiluka, L.J.M.; Chenyambuga, S.W.; Kaltenborn, B.P. Awareness and perceptions of local people about wildlife hunting in western Serengeti communities. Trop. Conserv. Sci. 2012, 5, 208-224. [CrossRef]

17. Duffy, R. War, by conservation. Geoforum 2016, 69, 238-248. [CrossRef]

18. Fiallo, E.A.; Jacobson, S.K. Local communities and protected areas: Attitudes of rural residents towards conservation and Machalilla National Park, Ecuador. Environ. Conserv. 1995, 22, 241-249. [CrossRef]

19. Kaltenborn, B.P.; Bjerke, T. The relationship of general life values to attitudes toward large carnivores. Human Ecol. Rev. 2002, $9,55-61$. 
20. Berkes, F. Sacred Ecology. In Traditional Ecological Knowledge and Resource Management, 2nd ed.; Taylor \& Francis: Philadelphia, PA, USA, 2008.

21. Afriyie, O.J.; Asare, M.O. Use of Local Ecological Knowledge to Detect Declines in Mammal Abundance in Kogyae Strict Nature Reserve, Ghana. Environ. Manag. 2020, 66, 997-1011. [CrossRef]

22. Kaltenborn, B.P.; Bjerke, T.; Vitterso, J. Attitudes toward large carnivores among sheep farmers, wildlife managers, and research biologists in Norway. Human Dimen. Wildl. 1999, 4, 57-73. [CrossRef]

23. Røskaft, E.; Hagen, M.L.; Hagen, T.L.; Moksnes, A. Patterns of outdoor recreation activities among Norwegians: An evolutionary approach. Ann. Zool. Fenn. 2004, 41, 609-618.

24. Fa, J.E.; Brown, D. Impacts of hunting on mammals in African tropical moist forests: A review and synthesis. Mammal. Rev. 2009, 39, 231-264. [CrossRef]

25. Abernethy, K.A.; Coad, L.; Taylor, G.; Lee, M.E.; Maisels, F. Extent and ecological consequences of hunting in Central African rainforests in the twenty-first century. Philos. Trans. R. Soc. B. 2013, 368, 20120303. [CrossRef]

26. Mwakatobe, A.; Røskaft, E.; Nyahongo, J. Bushmeat and food security: Species preference of sundried bushmeat in communities in the Serengeti-Mara ecosystem, Tanzania. Afr. J. Biodivers. Conserv. 2012, 4, 548-559.

27. Tengö, M.; Hill, R.; Malmer, P.; Raymond, C.M.; Spierenburg, M.; Danielsen, F.; Elmqvist, T.; Folke, C. Weaving knowledge systems in IPBES, CBD, and beyond-lessons learned for sustainability. Curr. Opin. Environ. Sustain. 2017, 26-27, 17-25. [CrossRef]

28. Oduro-Ofori, E.; Ocloo, E.K.A.; Peprah, C.; Effah, G. Assessing Natural Resource Use Conflicts in the Kogyae Strict Nature Reserve. Environ. Nat. Res. Res. 2015, 5, 56-71. [CrossRef]

29. Ayivor, J.S.; Ntiamoa-Baidu, Y. Assessing the socio-economic stressors of Ghana's only Strict Nature Reserve: Kogyae. Parks 2015, 21, 85-100. [CrossRef]

30. Ministry of Finance. The Composite Budget of the Sekyere Central District Assembly for the 2016 Fiscal Year. 2015. Available online: https://www.mofep.gov.gh/sites/default/files/composite-budget/2016/AR/Sekyere-Central.pdf (accessed on 28 February 2021).

31. Berkes, F. Sacred Ecology. In Traditional Ecological Knowledge and Resource Management; Taylor \& Francis: Philadelphia, PA, USA, 1999; pp. 1-20.

32. Ghana Statistical Service. 2010 Population and Housing Census of Ghana; Ghana Statistical Service: Accra, Ghana, 2014.

33. Gandiwa, E. Preliminary assessment of illegal hunting by communities adjacent to the northern Gonarezhou National Park, Zimbabwe. Trop. Conserv. Sci. 2011, 4, 445-467. [CrossRef]

34. Kothari, C.R. Research Methodology: Methods and Techniques, 2nd ed.; New Age International: New Delhi, India, 2004.

35. Krumpal, I. Determinants of social desirability bias in sensitive surveys: A literature review. Qual. Quant. 2013, 47, 2025-2047. [CrossRef]

36. Sabuhoro, E.; Wright, B.A.; Powell, R.B.; Hallo, J.C.; Layton, P.A.; Munanura, I.E. Perceptions and Behaviors of Indigenous Populations Regarding Illegal Use of Protected Area Resources in East Africa's Mountain Gorilla Landscape. Environ. Manag. 2020, 65, 410-419. [CrossRef]

37. Podsakoff, P.M.; MacKenzie, S.B.; Lee, J.Y.; Podsakoff, N.P. Common method biases in behavioral research: A critical review of the literature and recommended remedies. J. Appl. Psych. 2003, 88, 879. [CrossRef]

38. Fowler, F.J. Improving Survey Questions: Design and Evaluation; Sage: Thousand Oaks, CA, USA, 1995.

39. Bragagnolo, C.; Malhado, A.C.M.; Jepson, P.; Ladle, R.J. Modelling Local Attitudes to Protected Areas in Developing Countries. Conserv. Soc. 2016, 14, 163. [CrossRef]

40. Moore, J.F.; Mulindahabi, F.; Masozera, M.K.; Nichols, J.D.; Hines, J.E.; Turikunkiko, E.; Oli, M.K. Are ranger patrols effective in reducing poaching-related threats within protected areas? J. Appl. Ecol. 2018, 55, 99-107. [CrossRef]

41. Macdonald, D.W.; Johnson, P.J.; Albrechtsen, L.; Seymour, S.; Dupain, J.; Hall, A.; Fa, J.E. Bushmeat trade in the Cross-Sanaga Rivers Region: Evidence for the importance of protected areas. Biol. Conserv. 2012, 147, 107-114. [CrossRef]

42. Boakye, M.K.; Kotze, A.; Dalton, D.L.; Jansen, R. Unraveling the pangolin bushmeat commodity chain and the extent of trade in Ghana. Hum. Ecol. 2016, 44, 257-264. [CrossRef]

43. Haule, K.S.; Johnsen, F.H.; Maganga, S.L.S. Striving for sustainable wildlife management: The case of Kilombero Game Controlled Area, Tanzania. J. Environ. Manag. 2002, 66, 31-42. [CrossRef]

44. Sobrala, A.; La Torre-Cuadros, M.A.; Alves, R.R.N.; Albuquerque, U.P. Conservation efforts based on local ecological knowledge: The role of social variables in identifying environmental indicators. Ecol. Ind. 2017, 81, 171-181. [CrossRef]

45. Gore, M.L.; Kahler, J.S. Gendered risk perceptions associated with human-wildlife conflict: Implications for participatory conser vation. PLoS ONE 2012, 7, e32901. [CrossRef]

46. Ferreira, M.N.; Freire, N.C. Community perceptions of four protected areas in the Northern portion of the Cerrado hotspot, Brazil. Environ. Conserv. 2009, 36, 129-138. [CrossRef]

47. Larson, L.R.; Conway, A.L.; Krafte, K.E.; Hernandez, S.M.; Carroll, J.P. Community-based conservation as a potential source of conflict around a protected area in Sierra Leone. Environ. Conserv. 2016, 43, 242-252. [CrossRef]

48. Martino, D. Gender and Urban Perceptions of Nature and Protected Areas in Bañados del Este Biosphere Reserve. Environ. Manage. 2008, 41, 654. [CrossRef] [PubMed] 
49. Wiafe, E.D. Hunted species and hunting equipment used by rainforest poachers in Ghana. J. Threat. Taxa 2018, 10, 11285-11289. [CrossRef]

50. Critchlow, R.; Plumptre, A.J.; Driciru, M.; Rwetsiba, A.; Stokes, E.J.; Tumwesigye, C.; Wanyama, F.; Beale, C.M. Spatiotemporal trends of illegal activities from ranger-collected data in a Ugandan national park. Conserv. Biol. 2015, 29, 1458. [CrossRef]

51. Holmern, T.; Muya, J.; Røskaft, E. Local law enforcement and illegal bushmeat hunting outside the Serengeti National Park, Tanzania. Environ. Conserv. 2007, 34, 55-63. [CrossRef]

52. Lindsey, P.A.; Romañach, S.S.; Tambling, C.J.; Chartier, K.; Groom, R. Ecological and financial impacts of illegal bushmeat trade in Zimbabwe. Oryx 2011, 45, 96-111. [CrossRef]

53. Kuukyi, F.S.; Amfo-Otu, R.; Wiafe, E. Consumer views of bushmeat consumption in two Ghanaian markets. Appl. Res. J. 2014, 1,142 .

54. Boakye, M.K.; Agyemang, A.O.; Wiafe, E.D.; Dossou-Yovo, H.O.; Ziekah, M. Animals Traded for Traditional Medicine Purposes in the Kumasi Central Market, Ghana: Conservation Implications. Conservation 2021, 1, 113-120. [CrossRef]

55. Brashares, J.; Goldena, C.; Weinbauma, K.; Barrettc, C.; Okello, G. Economic and geographic drivers of wildlife consumption in rural Africa. Proc. Nat. Acad. Sci. 2011, 108, 13931-13936. [CrossRef]

56. Kangalawe, R.M.; Liwenga, E.T. Livelihoods in the wetlands of Kilombero Valley in Tanzania: Opportunities and challenges to integrated water resource management. Phys. Chem. Earth Parts A/B/C 2005, 30, 968-975. [CrossRef]

57. Knapp, E.J. Why poaching pays: A summary of risks and benefits illegal hunters face in Western Serengeti, Tanzania. Trop. Conserv. Sci. 2012, 5, 434-445. [CrossRef]

58. Gandiwa, E.; Heitkönig, I.M.A.; Lokhorst, A.M.; Prins, H.H.T.; Leeuwis, C. Illegal hunting and law enforcement during a period of economic decline in Zimbabwe: A case study of northern Gonarezhou National Park and adjacent areas. J. Nat. Conserv. 2013, 21, 133-142. [CrossRef]

59. Clarke, R.V.; de By, R.A. Poaching, habitat loss and the decline of neotropical parrots: A comparative spatial analysis. J. Exp. Criminol. 2013, 9, 333-353. [CrossRef]

60. Martin, A.; Rutagarama, E.; Gray, M.; Asuma, S.; Bana, M.; Basabose, A.; Mwine, M. Linking development interventions to conservation: Perspectives from partners in the International Gorilla Conservation Programme. Soc. Nat. Res. 2011, 24, 626-636. [CrossRef]

61. Salafsky, N. Integrating development with conservation. A means to a conservation end, or a mean end to conservation? Biol. Conserv. 2011, 144, 973-978. [CrossRef]

62. Munanura, I.; Backman, K.; Hallo, J.; Powell, R.; Sabuhoro, E. Understanding the relationship between livelihood constraints of poor forest-adjacent residents, and illegal forest use, at Volcanoes National Park, Rwanda. Conserv. Soc. 2018, 16, 1425. [CrossRef]

63. Soto, C.G. Socio-Cultural Barriers to Applying Fishers' Knowledge in Fisheries Management: An Evaluation of Literature Cases. Ph.D. Dissertation, Simon Fraser University, Burnaby, BC, Canada, 2006.

64. Parry, L.; Peres, C.A. Evaluating the use of local ecological knowledge to monitor hunted tropical-forest wildlife over large spatial scales. Ecol. Soc. 2015, 20, 15. [CrossRef]

65. Carmack, E.C.; Macdonald, R.W. Water-and ice-related phenomena in the coastal region of the Beaufort Sea: Some parallels between Native experience and Western science. Arctic 2008, 61, 265-280. [CrossRef]

66. Kahindi, O.; Wittemyer, G.; King, J.; Ihwagi, F.; Omondi, P.; Douglas-Hamilton, I. Employing participatory surveys to monitor the illegal killing of elephants across diverse land uses in Laikipia-Samburu, Kenya. Afri. J. Ecol. 2010, 48, 972-983. [CrossRef]

67. Munanura, I.E.; Backman, K.F.; Hallo, J.C.; Powell, R.B. Perceptions of tourism revenue sharing impacts on Volcanoes National Park, Rwanda: A Sustainable Livelihoods framework. J. Sust. Tour. 2016, 24, 1709-1726. [CrossRef] 